\title{
Resistant starch in the Italian diet*
}

\author{
Furio Brighenti†, M. Cristina Casiraghi and Cristina Baggio \\ Department of Food Science \& Microbiology, Nutrition Unit, University of Milan, Via Celoria no. 2, 20133 Milano, Italy
}

(Received 16 October 1997 - Revised 9 April 1998 - Accepted 12 May 1998)

\begin{abstract}
Resistant starch (RS) has been defined as the sum of starch and starch-degradation products that reach the human large intestine (Champ, 1994), and it is now regarded as a sub-fraction of starch with a positive impact on colonic welfare and lipid metabolism. An early estimate of the RS intake in Europe gave an average value of approximately 4 g/d (Dyssler \& Hoffem, 1994a). However, since no information is available for Italy, the aim of the present study was to estimate the intake of RS in the Italian diet by direct analysis of RS in a range of typical foods representing the main sources of starch intake in the country. The selection of representative foods and of food consumption data were based on published results of the National Food Consumption Study conducted during the 1980s by the National Institute of Nutrition on 10000 households, using weighed-food records plus inventory methodologies (Saba et al. 1990; Turrini et al. 1991). Three main groups of foods were considered: cereals (pasta, rice, bread and bread products, and pastries), potatoes, legumes. Different commercial brands for each sample were purchased, according to the known presence on the market. Samples were prepared 'as eaten' and submitted to simulated chewing, followed by total and resistant starch determination using the enzymic procedure published as a result of the EC Concerted Action EURESTA (Champ, 1992). From these results, the estimated average intake of RS in Italy was found to be $8.5 \mathrm{~g} / \mathrm{d}$, with regional differences (from $7 \cdot 2 \mathrm{~g} / \mathrm{d}$ in the north-west to $9 \cdot 2 \mathrm{~g} / \mathrm{d}$ in the south) mainly due to the different consumption of some typical Italian starchy food (bread, pasta, legumes).
\end{abstract}

\section{Resistant starch: Italian diet}

Resistant starch (RS) has been defined as the starch fraction in foods which is highly resistant to digestion by pancreatic amylase (EC 3.2.1.1; Englyst et al. 1982). This analytical definition is often coupled with a physiological definition, i.e. 'the sum of starch and starch-degradation products that reach the human large intestine' (Champ, 1994). The characteristics of RS are similar to those of insoluble fibres, since it does not affect postprandial insulin, glucose and free fatty acid response after a glucose load (Ranganathan et al. 1994) and, once in the colon, it moderately increases stool weight (Cummings et al. 1996). However, like soluble fibre, RS is a substrate for microbial fermentation, giving origin to endproducts, mainly short-chain fatty acids, and influencing lipid and $\mathrm{N}$ metabolism in human and animal studies (Cummings \& MacFarlane, 1991; De Deckere et al. 1993, 1995; Morand et al. 1994; Phillips et al. 1995; Younes et al. 1995 a,b). A particularity of RS is that its fermentation generates high levels of butyric acid compared with other fermentable carbohydrates (Englyst \& MacFarlane, 1986; Scheppach et al. 1988). Butyrate is an important substrate for the colonocyte, and appears to be of special relevance in relation to the welfare of the epithelium of the colon. Deficiency of luminal butyrate leads to an energy-deficient state for the colonocyte, and thus to atrophy of the mucosa (Roedinger, 1990). Moreover, butyrate is a potent inducer of differentiation of tumour cells (Whitehead et al. 1986), and it is able to slow down proliferation in a number of colorectal cancer cell lines, possibly by arresting cells in the G1 phase of the cell cycle (Barnard \& Warwick, 1992). A possible relevance of RS for colonic cancer prevention is suggested by experimental human studies. It has been demonstrated that RS reduces mucosal proliferation in rectal biopsies (Van Munster et al. 1994), a biomarker of cancer risk, probably by interfering with bile acids metabolism (Verbeek et al. 1995), and that it reduces bacterial $\beta$ glucosidase (EC 3.2.1.21) activity and faecal concentration of secondary bile acids, neutral sterols and sterol metabolites (Hylla et al. 1998), all factors related to cancer risk. Cassidy et al. (1994) found a significant and inverse relationship between the incidence of colon cancer and dietary intake of starch in a cross-country observational

\footnotetext{
Abbreviations: INN, National Institute of Nutrition; RS, resistant starch; RS1, starch which is resistant as a consequence of encapsulation in the food structure; RS2, native B-type starch; RS3, retrograded amylose; TS, total starch.

* This work was presented in part at the 16th International Congress of Nutrition, 27 July-1 August 1997, Montreal, Canada.

$\dagger$ Corresponding author: Dr Furio Brighenti, fax +392 70638625, email furio.brighenti@unimi.it
} 
Table 1. Types and characteristics of the foods analysed

\begin{tabular}{|c|c|c|c|}
\hline \multirow[b]{2}{*}{ Main group } & \multirow[b]{2}{*}{ Sub-group } & \multicolumn{2}{|c|}{ Categories } \\
\hline & & Ingredients or variety & Processing \\
\hline \multirow[t]{4}{*}{ Cereals } & Pasta & Durum wheat, eggs & $\begin{array}{l}\text { Industrial or home-made drying, } \\
\text { surface area }\end{array}$ \\
\hline & Rice & $\begin{array}{l}\text { S. Andrea, Padano, Originario, } \\
\text { Arborio, Carnaroli }\end{array}$ & $\begin{array}{l}\text { Different recipes with low or high water } \\
\text { availability during cooking }\end{array}$ \\
\hline & $\begin{array}{l}\text { Bread } \\
\text { products }\end{array}$ & White flour, wholemeal flour, oil & Yeast-leavened or sourdough-fermented \\
\hline & Pastries & & $\begin{array}{l}\text { Different recipes, different degree of } \\
\text { gelatinization of starch in the product }\end{array}$ \\
\hline \multirow[t]{2}{*}{ Potatoes } & Potatoes & White or yellow & Low or high water availability during cooking \\
\hline & Dumplings & Wheat flour & Cooling and reheating \\
\hline Legumes & & Peas, lentils, beans, chickpeas* & Frozen, dried, canned \\
\hline
\end{tabular}

* Pisum sativum, Lens esculenta, Phaseolus vulgaris, Cicer arietinum respectively.

study, suggesting that, together with NSP, RS present in normal human diets could contribute to the protection against colo-rectal cancer.

Although RS naturally occurs in cereals and vegetables, generally encapsulated within plant cells or tissue structures, most of the RS in the diet is present as a result of food processing (Muir et al. 1995). The formation of RS in food processing seems to be related in particular to the amylose content, to water availability and to starch-lipid interaction (Bravo et al. 1994; Eerlingen et al. 1994).

The heterogeneity of starchy foods, together with methodological considerations, is a major problem in the evaluation of the amount of RS in the human diets.

Early estimations of RS, considered as the starch escaping digestion, were derived in individual foods or in controlled experimental diets either directly by analysis of starch output in ileostomy effluents (Englyst \& Cummings, 1985, 1987; Muir et al. 1995; Silvester et al. 1995) and ileal intubation of healthy volunteers (Stephen et al. 1983; Faisant et al 1995), or indirectly by breath $\mathrm{H}_{2}$ measurements (Wolever et al. 1986a; Levitt et al. 1987). Results vary, in relation to the method used and to the food investigated, from a minimum value of $3-4 \%$ of the total starch (TS) intake to a maximum of $10-20 \%$ of the TS intake. On the other hand, analysis of food items using in vitro methods, such as those proposed by Englyst et al. (1992) and Champ (1992), once applied to food consumption data obtained from national surveys, gave an indirect estimation of $4 \mathrm{~g} / \mathrm{d}$ as the average RS intake in Europe (Dysseler \& Hoffem, 1994a).

Since, to our knowledge, no values exist regarding RS intake in Italy, we analysed the RS content in a range of food, representing the major contributors of starch in the Italian diet, then we used the results to estimate the daily RS intake on the basis of Italian food consumption data.

\section{Methods}

\section{Sample selection}

Food selection was based on information published by the National Institute of Nutrition (INN) about food consumption in Italy (Saba et al. 1990; Turrini et al. 1991). The published information were also used in order to choose the preserving technique or for recipes. The INN survey covered a sample of about 10000 households distributed throughout the whole country. The method adopted was a mixture of a direct and indirect survey based on weight and on inventory with an open list of food items. The household consumption of foods for 1 week was calculated as the difference between amounts entered daily in the household and the quantity registered at the final inventory, minus the amounts wasted daily, given as gifts or consumed by guests. All the amounts were obtained by weighing the quantities using a scale, under the supervision of dietitians. The items and categories reported in the INN survey were adopted to select the foods to be analysed for RS content. Three main groups of foods were considered: cereals, potatoes and legumes. In each group, different characteristics and processing conditions of food products were considered (Table 1).

Among cereals, foods were further divided into four subgroups: pasta, rice, breads, pastries. The pasta sub-group was divided into three categories: short and long dry pastas and egg pasta. For all pasta products, items from three leading companies (two industrial, one semi-industrial), covering about $55 \%$ of the national market, were purchased from supermarkets. For each category, analytical values of different brands were averaged.

Five varieties of rice, covering about $80 \%$ of varieties commonly consumed in Italy were chosen, and purchased from supermarkets.

The bread sub-group was divided into two categories: bread and bread products. Bread was further divided into sourdough-leavened, yeast-leavened, wholemeal, 'oil' bread and pizza. Bread products were breadsticks, white and wholemeal crispbread, white and wholemeal crackers. Products from different brands were purchased either from supermarkets or (in the case of fresh bread) from local bakery stores.

Pastries were divided into semi-sweet biscuits, shortsweet biscuits and artificially-leavened cakes. For each category, a range of products of different brands were purchased from supermarkets and bakery stores, then pooled and analysed.

The potato group was divided further into yellow and white potatoes. For each type of potato, two different cooking procedures were adopted: boiling in salted water 
or roasting. White potatoes were also analysed as potato dumplings. All products were purchased from local markets in the autumn and winter periods.

The legume group was divided into beans (Phaseolus vulgaris), peas (Pisum sativum), lentils (Lens esculenta) and chickpeas (Cicer arietinum). Two different varieties of beans were obtained, Romano beans and White beans. All products were further divided into dry, canned and (for beans and peas) frozen products. For each legume, different brands of canned and frozen products were purchased from local supermarkets; dried legumes were purchased from a local grocery store. Analytical values for the different variety of beans were averaged.

\section{Sample preparation and analysis}

Samples were analysed 'as eaten'. Products directly edible (i.e. breads, bread products and pastries) were minced in a Waring blender. Products normally eaten after boiling, such as pasta, potatoes and legumes, were boiled in salted water $(50 \mathrm{~g} \mathrm{NaCl} / 1)$ following cooking instructions on the packets. Dried legumes were re-hydrated for $12 \mathrm{~h}$ before cooking. Rice was cooked according to two different recipes, boiling in salted water and pan-cooking (risotto). Risotto is a typical recipe in Northern Italy, consisting of gradual addition of water during cooking so that no starch is lost in the cooking liquid. Roasted potatoes were peeled, cut into quarters and baked using a thermo-convection oven at $250^{\circ}$ for $20 \mathrm{~min}$.

All samples were analysed for moisture, TS and RS. TS and RS were determined using the enzymic procedure proposed by Champ (1992), modified by introducing a simulated chewing step for the analysis of moist foods. To this purpose, just after cooking, warm samples were forced through a $1.5 \mathrm{~mm}$ steel sieve by means of a glass pestle. Sample portions of the extruded moist food or of the minced dry food, calculated to contain about $100 \mathrm{mg}$ starch, were then dispersed in $0 \cdot 1 \mathrm{M}$-Tris maleate buffer, hydrolysed for $16 \mathrm{~h}$ with pancreatic $\alpha$-amylase, extracted with ethanol $(800 \mathrm{ml} / \mathrm{l})$, and the dry residues redispersed in $2 \mathrm{M}-\mathrm{KOH}$ and hydrolysed with amyloglucosidase (EC 3.2.1.3). Free glucose was then analysed using a glucose analyser (YSI 2300; Yellow Spring Instruments, Yellow Spring, OH, USA) and reported in polymeric form to calculate RS. Results obtained as described were used to evaluate the mean daily RS intake for the Italian population.

For this purpose, consumption values for starchy foods obtained in the INN survey were used. The RS values for individual foods or food categories or sub-groups were used in order to match as close as possible all food categories reported in the survey. The amounts of foods considered to represent intake were recalculated on a dry weight basis and, using TS and RS contents derived from analysis, daily TS and RS intakes were calculated.

\section{Statistical analysis}

Values are expressed on dry weight basis as means with their standard errors. Values were subjected to one-way ANOVA and differences among products were checked by post hoc Tukey HSD test.
Table 2. Resistant starch (RS) in the main food groups in the Italian diet $^{*}$

(Mean values with their standard errors for the no. of determinations indicated)

\begin{tabular}{lccr}
\hline & \multicolumn{3}{c}{ RS (g/kg dry wt) } \\
\cline { 2 - 4 } & Mean & SE & $n$ \\
\hline Cereals & $32 \cdot 2^{\mathrm{a}}$ & $1 \cdot 6$ & 100 \\
Potatoes & $56 \cdot 7^{\mathrm{b}}$ & $2 \cdot 5$ & 22 \\
Legumes & $116 \cdot 8^{\mathrm{c}}$ & $3 \cdot 9$ & 41 \\
\hline
\end{tabular}

a,b,c Mean values in the same column not sharing a common superscript letter were significantly different $(P<0.05)$

${ }^{*}$ For details of procedures, see p. 334 .

\section{Results}

\section{Resistant starch content of foods}

The mean RS values for the three main food groups are shown in Table 2. In general, the foods which are most frequently consumed in Italy contain different levels of RS; on dry weight basis, cereals showed the lower, potatoes the medium and legumes the higher RS content.

Table 3 reports the mean RS values for the four subgroups of cereal foods. Tables 4-7 report the mean RS values, differentiated by the variety or processing conditions, for each food item.

Among pasta products (Table 4), egg noodles showed a significantly $(P<0.05)$ higher content of RS.

For rice products (Table 5), the variety significantly affected the RS content of boiled products; on the otherhand, there were no differences in the RS contents among varieties for the pan-cooked rice. Also, the RS contents of two varieties (i.e. Originario and S. Andrea) were significantly affected by cooking conditions.

Among bread products, pizza and sourdough bread showed the highest RS content, similar to those observed in white and wholemeal crispbreads (Table 6).

In pastries, artificially-leavened cakes showed a significantly $(P<0.05)$ lower RS content than biscuits (Table 7). The RS contents of the biscuits were not affected by the composition or processing.

For potatoes (Table 8), neither variety nor home processing (i.e. boiling in salted water, oven roasting or dumpling preparation) produced significantly different levels of RS.

No differences in RS content were found between legume varieties (Table 9). The techniques of preservation had a

Table 3. Resistant starch (RS) in cereal foods in the Italian diet* (Mean values with their standard errors for the no. of determinations indicated)

\begin{tabular}{llcr}
\hline & \multicolumn{3}{c}{ RS (g/kg dry wt) } \\
\cline { 2 - 4 } & Mean & SE & $n$ \\
\hline Pasta & $37 \cdot 1^{\mathrm{a}}$ & $3 \cdot 3$ & 9 \\
Rice & $50 \cdot 9^{\mathrm{b}}$ & $2 \cdot 0$ & 30 \\
Bread & $21 \cdot 7^{\mathrm{cd}}$ & $1 \cdot 3$ & 52 \\
Pastries & $22 \cdot 3^{\mathrm{d}}$ & $3 \cdot 7$ & 9 \\
\hline
\end{tabular}

$\overline{a, b, c, d}$ Mean values in the same column not sharing a common superscript letter were significantly different $(P<0.05)$.

${ }^{*}$ For details of procedures, see p. 334 
Table 4. Resistant starch (RS) in pasta in the Italian diet* (Mean values with their standard errors for three determinations)

\begin{tabular}{llr}
\hline & \multicolumn{2}{c}{$R S(g / k g$ dry wt) } \\
\cline { 2 - 3 } & Mean & SE \\
\hline Egg noodles & $49 \cdot 1^{\mathrm{a}}$ & $6 \cdot 8$ \\
Spaghetti & $28 \cdot 4^{\mathrm{b}}$ & $2 \cdot 6$ \\
Short pasta & $33 \cdot 9^{\mathrm{ab}}$ & $3 \cdot 5$ \\
\hline
\end{tabular}

a,b Mean values in the same column not sharing a common superscript letter were significantly different $(P<0.05)$.

${ }^{*}$ For details of procedures, see p. 334

significant $(P<0.05)$ effect on RS levels only for beans and peas, the highest values being found in the canned product.

\section{Resistant starch intake in Italy in the $1980-4$ period}

Table 10 reports values for consumption of different foods containing starch, based on the INN food consumption survey (Saba et al. 1990; Turrini et al. 1991), and the calculated average daily intake of TS and RS. The estimated mean value for RS intake for Italy of $8.5 \mathrm{~g} / \mathrm{d}$ represented about $4 \%$ of the daily TS intake.

Fig. 1 shows the estimated daily intake of RS for the four main areas of Italy and the percentage of RS provided by the different foods considered. There was a geographical trend in RS consumption from northern to southern Italian regions.

Bread and pasta were the major sources of RS in all the areas, providing approximately $60 \%$ of the total amount of RS, followed by legumes in central and southern regions and by rice in northern areas (about 13 and $14 \%$ respectively).

\section{Discussion}

Despite the rise of interest in recent years concerning the potential of RS in improving human health, surprisingly little information is available on the presence of $\mathrm{RS}$ in foods

Table 5. Resistant starch (RS) in boiled and pan-cooked varieties of rice in the Italian diet†

(Mean values with their standard errors for three determinations, except all varieties with fifteen determinations)

\begin{tabular}{|c|c|c|c|c|}
\hline \multirow[b]{3}{*}{ Variety } & \multicolumn{4}{|c|}{ RS (g/kg dry wt) } \\
\hline & \multicolumn{2}{|c|}{ Boiled } & \multicolumn{2}{|c|}{ Pan-cooked } \\
\hline & Mean & SE & Mean & SE \\
\hline All varieties & $52 \cdot 2$ & $3 \cdot 8$ & $49 \cdot 6$ & $1 \cdot 3$ \\
\hline Padano & $51 \cdot 0^{\mathrm{ac}}$ & $3 \cdot 1$ & $55 \cdot 6$ & 1.9 \\
\hline Originario & $70 \cdot 4^{b}$ & $6 \cdot 6$ & $47 \cdot 1^{*}$ & $2 \cdot 0$ \\
\hline S. Andrea & $66 \cdot 1^{\mathrm{bc}}$ & 0.5 & $47 \cdot 0^{*}$ & 0.4 \\
\hline Arborio & $44 \cdot 2^{a}$ & $1 \cdot 7$ & $49 \cdot 7$ & 3.8 \\
\hline Carnaroli & $39 \cdot 5^{a}$ & $2 \cdot 5$ & $49 \cdot 1$ & 1.5 \\
\hline
\end{tabular}

a,b,c Mean values in the same column not sharing a common superscript letter were significantly different $(P<0.05)$.

Mean values were significantly different from those for the same variety boiled: ${ }^{*} P<0.05$.

†For details of procedures, see p. 334.
Table 6. Resistant starch (RS) in bread products in the Italian diet ${ }^{\star}$ (Mean values with their standard errors for the no. of determinations indicated)

\begin{tabular}{lllr}
\hline & \multicolumn{3}{c}{ RS (g/kg dry wt) } \\
\cline { 2 - 4 } & Mean & SE & $n$ \\
\hline Sourdough bread & $32 \cdot 3^{\text {acd }}$ & $3 \cdot 4$ & 6 \\
Yeast-leavened bread & $18 \cdot 6^{\text {bd }}$ & $2 \cdot 8$ & 6 \\
Wholemeal bread & $20 \cdot 8^{\mathrm{d}}$ & $3 \cdot 2$ & 6 \\
'Oil' bread & $11 \cdot 1^{\mathrm{bd}}$ & $2 \cdot 1$ & 6 \\
Pizza & $39 \cdot 5^{\mathrm{c}}$ & $3 \cdot 0$ & 3 \\
& & & \\
Crackers & $18 \cdot 4^{\mathrm{acd}}$ & $0 \cdot 8$ & 12 \\
Wholemeal crackers & $13 \cdot 1^{\mathrm{c}}$ & $0 \cdot 5$ & 3 \\
Breadsticks & $24 \cdot 1^{\mathrm{d}}$ & $4 \cdot 0$ & 4 \\
Crispbread & $30 \cdot 8^{\mathrm{bd}}$ & $0 \cdot 5$ & 3 \\
Wholemeal crispbread & $30 \cdot 9^{\mathrm{bd}}$ & $1 \cdot 6$ & 3 \\
\hline
\end{tabular}

a,b,c,d Mean values in the same column not sharing a common superscript letter were significantly different $(P<0.05)$.

${ }^{*}$ For details of procedures, see p. 334.

and on its intake in the diet. This could be due to: (1) the fact that RS is actually the sum of different starch fractions which can resist digestion in the upper gastrointestinal tract, and that in foods a wide heterogeneity of RS can be expected, related to ingredients, industrial and domestic processes; (2) the limits of analytical procedures employed to evaluate RS.

The first procedure described to determine RS (Englyst $e t$ al. 1982) included milling and boiling, and was thus capable of estimating only the retrograded amylose fraction (RS3) present in foods. The modified procedure introduced by Berry (1986) avoided the boiling step, hence making it possible to estimate also the native B-type starch fraction (RS2). This method was further modified by Champ (1992), by eliminating the pullulanase (EC 3.2.1.41) hydrolysis step, and was submitted to an interlaboratory evaluation in the framework of the EC Concerted Action EURESTA. However, in this procedure, the samples are usually dried and milled before analysis, thus preventing the determination of the fraction of starch which is resistant as a consequence of encapsulation in the food structure (RS1). Moreover, the most-commonly-adopted procedures for sample preparation (i.e. air-drying, freeze-drying) are likely to produce artefacts in the RS3 fraction, since the samples are cooled, heated, or frozen, thus potentially affecting starch retrogradation.

In the present work, we wanted to analyse RS as the sum

Table 7. Resistant starch (RS) in pastries in the Italian diet* (Mean values with their standard errors for three determinations)

\begin{tabular}{lll}
\hline & \multicolumn{2}{c}{$\mathrm{RS}(\mathrm{g} / \mathrm{kg}$ dry wt) } \\
\cline { 2 - 3 } & Mean & $\mathrm{SE}$ \\
\hline Semi-sweet biscuits & $28 \cdot 6^{\mathrm{a}}$ & $1 \cdot 0$ \\
Short-sweet biscuits & $27 \cdot 4^{\mathrm{a}}$ & $1 \cdot 6$ \\
Artificially-leavened cakes & $10 \cdot 8^{\mathrm{b}}$ & $1 \cdot 4$ \\
\hline
\end{tabular}

a,b Mean values in the same column not sharing a common superscript letter were significantly different $(P<0.05)$.

* For details of procedures, see p. 334 . 
Table 8. Resistant starch (RS) in different types of potato after different cooking procedures in the Italian diet ${ }^{*}$

(Mean values with their standard errors for the no. of determinations indicated)

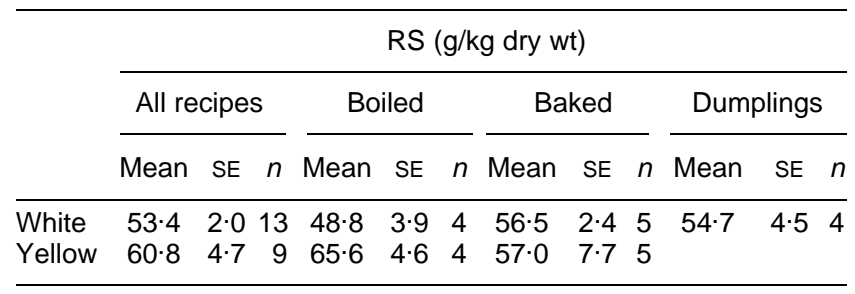

of all RS types present in different foods as they are normally consumed (i.e. cooked or raw, warm or cold, moist or dry). To this purpose, we adopted Champ's (1992) procedure but, in the sample preparation, we avoided treatments such as drying, milling and cooling, to eliminate as much as possible the production of artefacts, and we introduced a simulated chewing step by extruding moist foods through a steel sieve.

Similarly, Englyst et al. (1992) introduced a simulated chewing step in his procedure, by mincing samples before incubation. Muir \& O'Dea (1992), and more recently Åkerberg et al. (1998), introduced a standardized chewing step to prepare the sample for in vitro hydrolysis. All these methods have been validated against ileostomy studies conducted using the same or similar foods, and seem to give more realistic values compared with mechanical disintegration, so that it is possible to include RS2 in the analysis.

If underestimation of RS seems unlikely to have occurred in the present study due to the modifications in sample preparation with respect to the original procedure, a certain degree of overestimation could still be present.

In fact, the analytical method employed does not include all the enzymic steps which normally occur in vivo, and thus it is possible that for foods with a tight network of protein surrounding starch granules, $\alpha$-amylase access could have been impaired. Goni et al. (1996) found that including a proteolytic step in the hydrolysis procedure lowered the RS value from $19 \cdot 3$ to $16 \cdot 3 \mathrm{~g} / \mathrm{kg}$ in wheat flour and from 89 to $82 \mathrm{~g} / \mathrm{kg}$ in lentil flour. We were aware of this problem but, due to the large number of samples analysed, we accepted the relatively small inaccuracy of Champ's (1992) method, which was balanced by the higher ease of execution, better reproducibility and lower cost compared with other procedures (Dysseler \& Hoffem, 1994b). Furthermore, it must be pointed out that other individual factors are not controllable in an in vitro method. The actual chewing habits, the presence of other food components within a meal (Olesen \& Gudmand-Hoyer, 1997), the amount of starch consumed in a single meal or the gastrointestinal transit time (Chapman et al. 1985), or individual differences in intestinal physiology (Thornton et al. 1987) have all been demonstrated as having an effect on the amount of starch which escapes digestion. Thus, any RS database compiled on the basis of analytical methods (the present study included), should not be relied on completely to provide absolute values for individuals, although it could be useful for ranking foods, or for population studies.

Among starchy foods, cereal-based products are the most important sources of starch in the human diet, bread being the most important source of cereals. In Italy during the early 1980s, the estimated daily intake of bread ranged from 110 to $180 \mathrm{~g} / \mathrm{d}$ depending on regional food habits, with a national mean of about $160 \mathrm{~g} / \mathrm{d}$, which represented more than $40 \%$ of the total daily intake of starch. Thus, it is not surprising that RS from bread constituted a considerable proportion of RS introduced daily. The value of $2.6 \mathrm{~g} \mathrm{RS} / \mathrm{d}$ for bread estimated in the present study is similar to that calculated for the same food in Spain (Dysseler \& Hoffem, 1994a), and it is about fivefold greater than the value reported for other European countries (Dysseler \& Hoffem, 1994a).

In bread and similar products, RS content has been related to starch retrogradation during staling (Kulp \& Ponte, 1981). A high content of RS was found by Liljeberg \& Bjorck (1994) in pumpernickel rye bread made with sourdough leavening using long fermentation and baking times. We obtained similar results in Italian sourdough bread. This product is typical of southern regions of Italy, and generally prepared with durum wheat. The presence of organic acids produced during fermentation could facilitate the formation of RS, possibly through a debranching of the amylopectin moiety during baking. It has been shown, in fact, that debranched amylopectin may form a high level of RS on heat treatments (Berry, 1986). On the contrary, the low RS levels observed in 'oil' breads, mainly consumed in the most affluent areas of the country, were unexpected, since it has

Table 9. Resistant starch (RS) in legumes processed differently in the Italian diet*

(Mean values with their standard errors for the no. of determinations indicated)

\begin{tabular}{|c|c|c|c|c|c|c|c|c|c|c|c|c|}
\hline & \multicolumn{12}{|c|}{ RS g/kg dry wt } \\
\hline Beans $\dagger$ & $116 \cdot 0$ & $5 \cdot 3$ & 14 & $99 \cdot 6^{b}$ & $6 \cdot 4$ & 5 & $133 \cdot 0^{\mathrm{a}}$ & $1 \cdot 7$ & 5 & $114 \cdot 2^{\mathrm{ab}}$ & $5 \cdot 7$ & 4 \\
\hline Peast & $124 \cdot 1$ & $10 \cdot 7$ & 11 & $128 \cdot 9^{\mathrm{ab}}$ & $5 \cdot 2$ & 4 & $143 \cdot 8^{b}$ & 1.5 & 3 & $89 \cdot 7^{\mathrm{a}}$ & $24 \cdot 1$ & 4 \\
\hline Lentils† & $114 \cdot 4$ & $7 \cdot 5$ & 8 & $102 \cdot 0$ & 0.5 & 4 & $126 \cdot 8$ & $5 \cdot 9$ & 4 & & & \\
\hline
\end{tabular}

\footnotetext{
a,b Mean values in the same line not sharing a common superscript letter were significantly different $(P<0.05)$.

${ }^{*}$ For details of procedures, see p. 334.
}

†Phaseolus vulgaris, Pisum sativum, Lens esculenta, Cicer arietinum respectively. 
Table 10. Starchy food consumption* and estimated daily intakes of total starch (TS) and resistant starch (RS) in the Italian population

\begin{tabular}{lrrr}
\hline Food & $\begin{array}{c}\text { Amount } \\
(\mathrm{g} / \mathrm{d})\end{array}$ & $\begin{array}{c}\mathrm{TS} \\
(\mathrm{g} / \mathrm{d})\end{array}$ & $\begin{array}{c}\mathrm{R} \\
(\mathrm{mg} / \mathrm{d})\end{array}$ \\
\hline White bread & $158 \cdot 0$ & $93 \cdot 2$ & 2608 \\
Other breads & $6 \cdot 9$ & $3 \cdot 4$ & 111 \\
Breadsticks, crackers & $6 \cdot 6$ & $4 \cdot 4$ & 131 \\
Pasta & $80 \cdot 1$ & $57 \cdot 6$ & 2489 \\
Rice & $15 \cdot 2$ & $12 \cdot 0$ & 729 \\
Legumes; Fresh or frozen & $13 \cdot 9$ & $1 \cdot 4$ & 344 \\
$\quad$ Canned & $7 \cdot 1$ & $0 \cdot 4$ & 257 \\
$\quad$ Dried & $5 \cdot 0$ & $2 \cdot 3$ & 459 \\
Potatoes & $55 \cdot 3$ & $8 \cdot 8$ & 656 \\
Other starchy foods & $62 \cdot 0$ & $31 \cdot 0$ & 742 \\
& & & \\
Total & & $214 \cdot 2$ & 8525 \\
\hline
\end{tabular}

* Based on the National Institute of Nutrition food consumption survey (Saba et al. 1990; Turrini et al. 1991).

been shown that starch-lipid interactions may impair starch availability to enzymic digestion (Elliason \& Krog, 1985). As there is a qualitative and quantitative difference in the consumption of bread products, so the percentage of RS introduced can vary between regions by more than $10 \%$.

Pasta products have been reported to elicit reduced glycaemic responses (Wolever et al. 1986b; Monge et al. 1990), and thus to induce the metabolic advantages of low glycaemic index food (Jenkins et al. 1987). In addition to this potential, we found that pasta was the second main source of RS in the Italian diet, since it contributed to the daily RS intake by a mean amount of $2.5 \mathrm{~g} / \mathrm{d}(29 \%$ of the total daily RS intake). Processing, with its effects on starch structure, is the main determinant of starch susceptibility to $\alpha$-amylolysis in pasta (Pagani et al. 1986; Monge et al. 1990). However, the pasta surface area does not relate to the glycaemic response (Wolever et al. 1986b). Similarly, the shape of pasta does not seem important in relation to the RS if compared with the ingredients. The significantly high RS content of egg noodles might be related to the interaction between starch and protein present in eggs. However, the high RS levels in egg pasta had a limited effect on the daily RS intake, since in Italy the consumption of noodles represented only one-tenth of the total daily pasta consumption (Turrini et al. 1991).

In northern regions rice was the third main source of RS. In these areas rice consumption contributes about 13-16\% of the total RS intake compared with $6 \cdot 5-7 \%$ of the total RS intake in southern and central regions. The method of cooking and the variety of rice have significant effects on the RS content. Differences among varieties could be due to differences in the amylose content (amylose being one of the main determinants of RS in refined products), whereas the influence of the cooking method could derive from different amounts of starch leaking into the cooking liquid.

In central and southern regions of Italy there is less rice in the diet, with legumes making up about $12-14 \%$ of the total daily RS intake. Moreover, in the south of Italy legumes were fresh, frozen or dried, while in the North canned

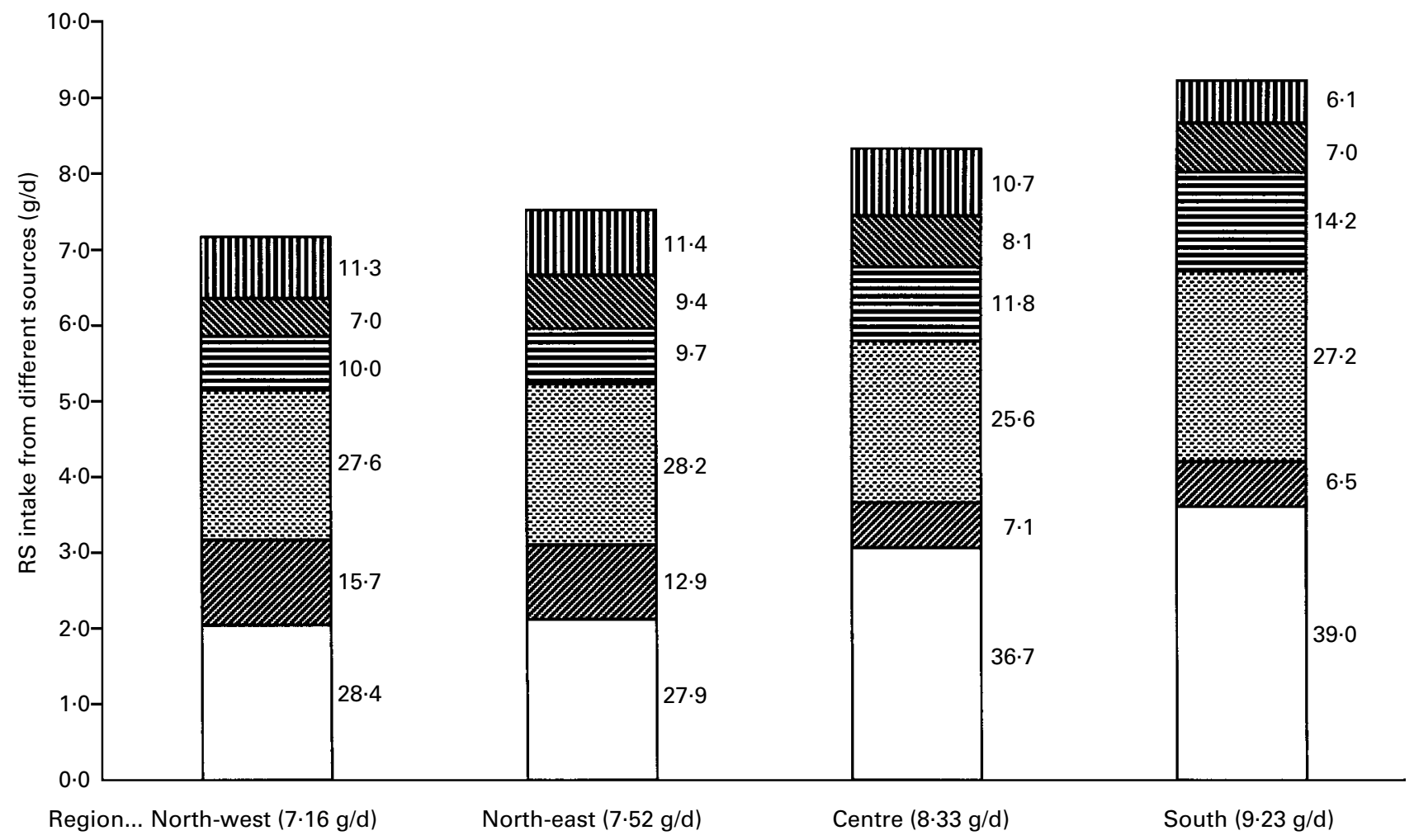

Fig. 1. Daily resistant starch (RS) consumption ( $\mathrm{g} / \mathrm{d}$ ) and percentages of RS provided by different foods in Italian regions. ( $\square$ ), Bread; (四), rice; (国), pasta; (目), legumes; $(\mathbb{Q})$, potatoes; $(\mathbb{W})$, others. 
products were more popular (Turrini et al. 1991). Legumes are known to have slow starch digestibility as a consequence of both their amylose content and of their rigid cell wall matrix (Wong et al. 1985; Wursch et al. 1986), and generally their starch digestibility is enhanced by drastic high-moisture heat processing such as canning (Johansen $e t$ al. 1994). However, our findings of a higher RS content in canned legumes compared with frozen and dry products are not contradictory. In fact, canned products undergo a hightemperature process followed by slow cooling, which, on one hand, could decrease the RS1 fraction by cell disruption; on the other hand, it increases RS3 as a consequence of amylose retrogradation.

The daily intake of RS $(8.5 \mathrm{~g})$ evaluated in the present study could be considered of nutritional importance. In fact, if we consider that from INN survey the estimated fibre intake in Italy in the period considered was about $21 \mathrm{~g} / \mathrm{d}$ (Saba et al. 1990), the concomitant consumption of $8.5 \mathrm{~g}$ $\mathrm{RS} / \mathrm{d}$ would lead to an increase of about $50 \%$ in the colonic load of undigested carbohydrates, thus enhancing the effects of colonic fermentation. Other studies have reported considerably lower values for RS in the diet of European countries, ranging from $3.22 \mathrm{~g} / \mathrm{d}$ in Norway to $5.74 \mathrm{~g} / \mathrm{d}$ in Spain (Dysseler \& Hoffem, 1994a). This difference could reflect the large amount of starchy food (bread, pasta, rice and legumes) consumed by the Italians in the early 1980s, or simply be due to a less-complete database for the RS contents of foods available in other countries. Our database can be considered complete, as it covers more than $90 \%$ of starch sources and more than $95 \%$ of starch intake. Moreover, the fact that there is a strict agreement between the daily amount of TS calculated by direct analysis of the foods we used to estimate the RS intake $(214.2 \mathrm{~g} / \mathrm{d})$ and the value reported by the authors of the survey using Italian food tables (212.8 g/d; Saba et al. 1990), testifies the correctness of our reclassification of the food sources. Moreover, the estimate that RS represents about $4 \%$ of TS is similar, if not lower than, other estimates used in international comparisons (Cassidy et al. 1994). However, it is possible that dietary habits have changed in Italy over the last 15 years, so that presently the daily RS intake could be lower. This possibility seems to be supported by the trend of data on Italian food intake provided by the Central Institute of Statistics (Istituto Centrale di Statistica, 1996), using diary plus interview methodologies on a sample of 3500 households. In the period 1984-95, individual consumption of bread and pasta decreased from 71.9 to $61.5 \mathrm{~kg} /$ year, and from 35.2 to $31.9 \mathrm{~kg} /$ year respectively.

International comparison (Cassidy et al. 1994) revealed a strong inverse relationship between the sum of NSP and RS intake (estimated from TS intake), and colo-rectal cancer incidence. However, many factors can confound this type of relationship, including substantial genetic and environmental differences in different populations. The present study has revealed that there is a north-south gradient in RS intake which reflects differences in dietary habits between geographical areas of Italy. In this type of within-country model such knowledge and the identity of the genetic background can facilitate the study of the relationship between RS intake and the incidence of colon cancer.

\section{References}

Åkerberg AKE, Liljeberg HGM, Granfeldt YE, Drews AW \& Björck IME (1998) An in vitro method based on chewing to predict resistant starch content in foods, allows parallel determination of potentially available starch and dietary fiber. Journal of Nutrition 128, 651-660.

Barnard JA \& Warwick G (1992) Sodium butyrate rapidly induces 'enterocytic-like' differentiation and growth inhibition of HT-29 cells. Gastroenterology 102, A199.

Berry CS (1986) Resistant starch: formation and measurement of starch that survives exhaustive digestion with amylolytic enzymes during the determination of dietary fibre. Journal of Cereal Science 4, 301-314.

Bravo L, Goni I, Fernandez-Martin F \& Saura-Calixto F (1994) Effect of deep-fat frying on resistant starch formation in potato chips. In Proceedings of the Concluding Plenary Meeting of EURESTA, April 1994. European Flair-Concerted Action no. 11 (COST 911), pp. 73-76 [N-G Asp, JMM van Amelsvoort and JGAJ Hautvast, editors]. Wageningen, The Netherlands: European Commission.

Cassidy A, Bingham SA \& Cummings JH (1994) Starch intake and colorectal cancer risk: an international comparison. British Journal of Cancer 69, 937-942.

Champ M (1992) Determination of resistant starch in foods and food products: interlaboratory study. European Journal of Clinical Nutrition 46, Suppl. 1, s51-s61.

Champ M (1994) Definition, analysis, physical, and chemical characterisation and intake of RS. In Proceedings of the Concluding Plenary Meeting of EURESTA, April 1994. European Flair-Concerted Action no. 11 (COST 911), pp. 1-11 [N-G Asp, JMM van Amelsvoort and JGAJ Hautvast, editors]. Wageningen, The Netherlands: European Commission.

Chapman RW, Sillery JK, Graham MM \& Saunders DR (1985) Absorption of starch by healthy ileostomates: effect of transit time and of carbohydrate load. American Journal of Clinical Nutrition 41, 1244-1248.

Cummings JH, Beatty ER, Kingman SM, Bingham SA \& Englyst HN (1996) Digestion and physiological properties of resistant starch in the human large bowel. British Journal of Nutrition $\mathbf{7 5}$, 733-747.

Cummings JH \& MacFarlane GT (1991) The control and consequences of bacterial fermentation in the human colon. Journal of Applied Microbiology 70, 443-459.

De Deckere EAM, Kloots WJ \& van Amelsvoort JMM (1993) Resistant starch decreases serum total cholesterol and triacylglycerol concentrations in rats. Journal of Nutrition 123, 21422151.

De Deckere EAM, Kloots WJ \& van Amelsvoort JMM (1995) Both raw and retrograded starch decrease serum triacylglycerol concentration and fat accretion in the rat. British Journal of Nutrition 73, 287-298.

Dysseler D \& Hoffem D (1994a) Estimation of resistant starch intake in Europe. In Proceedings of the Concluding Plenary Meeting of EURESTA, April 1994. European Flair-Concerted Action no. 11 (COST 911), pp. 84-86 [N-G Asp, JMM van Amelsvoort and JGAJ Hautvast, editors]. Wageningen, The Netherlands: European Commission.

Dysseler D \& Hoffem D (1994b) Ring test 1993-1994 for total and resistant starch determination: results and discussion. Comparison between Englyst's method and Berry's modified method on 20 different starchy foods. In Proceedings of the Concluding Plenary Meeting of EURESTA, April 1994. European FlairConcerted Action no. 11 (COST 911), pp. 87-98 [N-G Asp, JMM van Amelsvoort and JGAJ Hautvast, editors]. Wageningen, The Netherlands: European Commission. 
Eerlingen RC, Cillen G \& Delcour JA (1994) Enzyme-resistant starch. IV. Effect of endogenous lipids and added sodium dodecyl sulphate on formation of resistant starch. Cereal Chemistry 71, 170-177.

Elliason AC \& Krog N (1985) Physical properties of amylosemonoglyceride complexes. Journal of Cereal Science 3, 239248.

Englyst HN \& Cummings JH (1985) Digestion of the polysaccharides of some cereal foods in the human small intestine. American Journal of Clinical Nutrition 42, 778-787.

Englyst HN \& Cummings JH (1987) Digestion of the polysaccharides of potato in the small intestine of man. American Journal of Clinical Nutrition 45, 423-431.

Englyst HN, Kingman SM \& Cummings JH (1992) Classification and measurement of nutritionally important starch fractions. European Journal of Clinical Nutrition 46, Suppl. 2, s33-s50.

Englyst HN \& MacFarlane GT (1986) Breakdown of resistant and readily digestible starch by human gut bacteria. Journal of the Science of Food and Agriculture 37, 699-706.

Englyst HN, Wiggins HS \& Cummings JH (1982) Determination of the non-starch polysaccharides in plant foods by gas-liquid chromatography of constituent sugars as alditol acetates. Analyst 107, 307-318.

Faisant N, Buleon A, Colonna P, Molis C, Lartigue S, Galmiche JP \& Champ M (1995) Digestion of raw banana starch in the small intestine of healthy humans: structural features of resistant starch. British Journal of Nutrition 73, 111-123.

Goni I, Garcia-Diz L, Manas E \& Saura-Calixto F (1996) Analysis of resistant starch: a method for foods and food products. Food Chemistry 56, 445-449.

Hylla S, Gostner A, Dusel G, Anger H, Bartram HP, Christl SU, Kasper H \& Scheppach W (1998) Effects of resistant starch on the colon in healthy volunteers: possible implications for cancer prevention. American Journal of Clinical Nutrition 67, 136142.

Istituto Centrale di Statistica (1996) Rapporto annuale sui Consumi delle Famiglie (Annual report on household consumption). Rome: ISTAT.

Jenkins DJA, Wolever TMS, Collier GR, Ocana A, Rao AV, Buckley G, Lam Y, Mayer A \& Thompson LU (1987) Metabolic effects of low-glycemic-index diet. American Journal of Clinical Nutrition 46, 968-975.

Johansen HN, Bach Knudsen KE \& Eggum BO (1994) Starch digestibility of raw and processed peas. In Proceedings of the Concluding Plenary Meeting of EURESTA, April 1994. European Flair-Concerted Action no.11 (COST 911), pp. 122-125 [N-G Asp, JMM van Amelsvoort and JGAJ Hautvast, editors]. Wageningen, The Netherlands: European Commission.

Kulp K \& Ponte JG (1981) Staling of white bread: fundamental causes. CRC Critical Reviews in Food Science and Nutrition 15, $1-48$.

Levitt MD, Hirsh P, Fetzer CA, Sheahan M \& Levine AS (1987) $\mathrm{H}_{2}$ excretion after ingestion of complex carbohydrates. Gastroenterology 92, 383-389.

Liljeberg H \& Bjorck I (1994) Bioavailability of starch in bread products. Postprandial glucose and insulin responses in healthy subjects and in vitro resistant starch content. European Journal of Clinical Nutrition 48, 151-163.

Monge L, Cortassa G, Fiocchi F, Mussino G \& Carta Q (1990) Glyco-insulinaemic response, digestion and intestinal absorption of the starch contained in two types of spaghetti. Diabetes, Nutrition and Metabolism 3, 239-246.

Morand C, Levrat A-M, Besson C, Demigné C \& Rémésy C (1994) Effects of a diet rich in resistant starch on hepatic lipid metabolism in the rat. Journal of Nutritional Biochemistry 5, $138-144$.

Muir JG, Birkett A, Brown I \& O’Dea K (1995) Food processing and maize variety affects amounts of starch escaping digestion in the small intestine. American Journal of Clinical Nutrition 61, 82-89.

Muir JG \& O'Dea K (1992) Measurement of resistant starch: factors affecting the amount of starch escaping digestion in vitro. American Journal of Clinical Nutrition 56, 123-127.

Olesen M \& Gudmand-Hoyer E (1997) Maldigestion and colonic fermentation of wheat bread in humans and the influence of dietary fat. American Journal of Clinical Nutrition 66, 62-66.

Pagani MA, Gallant DJ, Bouchet B \& Resmini P (1986) Ultrastructure of cooked spaghetti. Food Microstructure 5, 111-129.

Phillips J, Muir JG, Birkett A, Lu ZX, Jones GP, O'Dea K \& Young GP (1995) Effect of resistant starch on faecal bulk and fermentation-dependent events in humans. American Journal of Clinical Nutrition 62, 121-130.

Ranganathan S, Champ M, Pechard C, Blanchard P, Nguyen M, Colonna P \& Krempf M (1994) Comparative study of the acute effects of resistant starch and dietary fibre on metabolic indexes in men. American Journal of Clinical Nutrition 59, 873-883.

Roedinger WEW (1990) The starved colon: diminished mucosal nutrition, diminished absorption and colitis. Diseases of the Colon and Rectum 33, 858-862.

Saba A, Turrini A, Mistura G, Cialfa E \& Vichi M (1990) Indagine nutrizionale sui consumi alimentari delle famiglie 1980-84 (Dietary survey on food consumption of households during 1980-84). La Rivista della Società Italiana di Scienza dell'Alimentazione 19, 53-65.

Scheppach W, Fabian C, Sachs M \& Kasper H (1988) The effect of starch malabsorption on fecal short-chain fatty acid excretion in man. Scandinavian Journal of Gastroenterology 23, 755-759.

Silvester KJ, Englyst HN \& Cummings JH (1995) Ileal recovery of starch from whole diets containing resistant starch measured in vitro and fermentation of ileal effluent. American Journal of Clinical Nutrition 62, 403-411.

Stephen AM, Haddad AC \& Phillips SF (1983) Passage of carbohydrate into the colon - Direct measurements in human. Gastroenterology 85, 589-595.

Thornton JR, Dryden A, Kelleher J \& Losowsky MS (1987) Superefficient starch absorption. A risk factor for colonic neoplasia? Digestive Diseases and Sciences 32, 1088-1091.

Turrini A, Saba A \& Lintas C (1991) Study of the Italian reference diet for monitoring food constituents and contaminants. Nutrition Research 11, 861-874.

Van Munster IP, Tangerman A \& Nagengast FM (1994) Effect of resistant starch on colonic fermentation, bile acid metabolism, and mucosal proliferation. Digestive Diseases and Sciences 39, 834-842.

Verbeek MJF, De Deckere EAM, Tijburg LBM, Van Amelsvoort JMM \& Beynen AC (1995) Influence of dietary retrograded starch on the metabolism of neutral steroids and bile acids in rats. British Journal of Nutrition 74, 807-820.

Whitehead RH, Young GP \& Bhathal PS (1986) Effects of short chain fatty acids on a new human colon carcinoma cell line (LIM1215). Gut 27, 1457-1463.

Wolever TMS, Cohen Z, Thompson LU, Thorne MJ, Jenkins MJA, Prokipchuk EJ \& Jenkins DJA (1986a) Ileal loss of available carbohydrate in man: comparison of a breath hydrogen method with direct measurement using a human ileostomy model. American Journal of Gastroenterology 81, 115-122.

Wolever TMS, Jenkins DJA, Kalmusky J, Giordano C, Giudici S, Jenkins AL, Thompson LU, Wong GS \& Josse RG (1986b) Glycemic response to pasta: effect of surface area, degree of cooking, and protein enrichment. Diabetes Care 9, 401-404.

Wong S, Trainedes K \& O'Dea K (1985) Factors affecting the rate of starch hydrolysis of starch in legumes. American Journal of Clinical Nutrition 42, 38-43.

Wursch P, Del Vedovo S \& Koellreuter B (1986) Cell structure and 
starch nature as key determinants of the digestion rate of starch in legumes. American Journal of Clinical Nutrition 43, 2529.

Younes H, Demigné C, Behr S \& Rémésy C (1995a) Resistant starch exerts a lowering effect on plasma urea by enhancing urea transfer into the large intestine. Nutrition Research 15, 1199 1210.

Younes H, Levrat A-M, Demigné C \& Rémésy C (1995b) Resistant starch is more effective than cholestyramine as lipidlowering agent in the rat. Lipids 30, 847-853. 


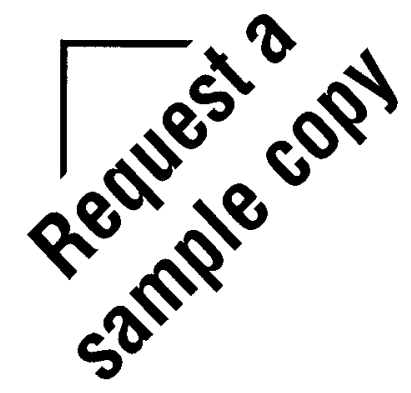

British

Journal of Nutrition

\author{
Editor-in-Chief \\ KN Frayn \\ Oxford Lipid Metabolism Group \\ Radcliffe Infirmary \\ Oxford, UK \\ Deputy Editors \\ SA Bingham (UK) \\ GE Lobley (UK) \\ B Sandström (Denmark) \\ Reviews Editor \\ DI Thurnham (UK) \\ Supplements Editor \\ CM Williams (UK)
}

Supported by an Editorial Board representing all of the subject specialities and geographical regions with an interest in human and animal nutrition

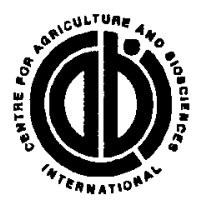

CAB INTERNATIONAL
The British Journal of Nutrition is an international, peerreviewed journal publishing original papers, review articles, short communications and technical notes on human and clinical nutrition, general nutrition, and animal nutrition. Correspondence is encouraged in a nutrition discussion forum. The journal recognizes the multidisciplinary nature of nutritional science and encourages the submission of material from all of the specialities involved in research and clinical practice. The journal also publishes supplements on topics of particular interest.

The British Journal of Nutrition is published monthly by CAB INTERNATIONAL on behalf of the Nutrition Society.

Coverage includes:

- International and public health nutrition

- Clinical metabolism and nutritional support

- Obesity and body composition

- Infant nutrition

- Diet selection

- Reproduction, growth and development

- Smoking and diet

- Nutrition and behaviour

- Animal nutrition and metabolism

- Companion animal nutrition

- Macronutrient metabolism

- Malnutrition

- Micronutrients

- Epidemiology

Supplements:

The 1998 volumes will feature a number of supplementary issues.

Monthly Contents List and Author Index

6th issue: Cumulative subject/contents and author index Directions to contributors in first issue of every volume

Also includes:

- Short Communications

- Technical Notes

- Nutrition Discussion Forum

- Book Reviews

First issued: 1947

ISSN: 0007-1145

Monthly publication 1998, Vols 79 and 80

Annual Subscription Rates (Printed)

£375.00 (\$680.00 Americas only)

To order your subscription or sample copy contact:

CAB INTERNATIONAL

Wallingford, Oxon, OX10 8DE, UK

Tel: +44 (0) 1491832111 Fax: +44 (0) 1491826090

E-mail: publishing@cabi.org

CAB INTERNATIONAL

198 Madison Avenue,

New York, NY10016-4314, USA

Tel: +1 (212) 7266490 Toll-free: 18005284841

Fax: +1 (212) 6867993 E-mail: cabi-nao@cabi.org 